\title{
DETERMINANT FACTORS OF TAX AVOIDANCE IN COMPANIES IN KOMPAS100
}

\author{
Wijayanti Inung, Putri Megadeanti Marhaen Shavrina, \\ Hadinugroho Listijowati, Mawardi Rizal \\ Faculty of Economics and Business, Perbanas Institute, Indonesia \\ *E-mail: inung@perbanas.id
}

\begin{abstract}
This research studies factors that can influence tax avoidance. These factors are leverage, company size, profitability, sales growth and the proportion of independent directors. The data used were obtained from the financial statements of manufacturing companies obtained in Kompas100 on the Indonesia Stock Exchange in the 2015-2018 period. The sample selection method used in this study is the purposive sampling method and the analysis technique used is multiple linear regression that contains the normality test, the classic assumption test and the hypothesis test. Total samples in the study were 8 companies. The results showed that only an increase in sales could affect tax avoidance, other factors that did not affect tax avoidance. Simultaneously these factors influence tax avoidance with a level of adjusted $\mathrm{R}$ squared 0.9188 .
\end{abstract}

\section{KEY WORDS}

Leverage, firm size, profitability, sales growth, independet commissioners, tax avoidance.

One of the biggest sources of income the country receives is the Prasetya tax (Sugitha and Supadhmi, 2013). Tax is a burden for a company, while for the government tax is a source of income. This will lead to differences in interests, from the government (fiscal authorities) will want continuous tax revenue while from companies will want minimum tax payments, so that will have an impact on corporate financial reporting and tax reporting (Kurniasih and Sari, 2013). The existence of differences in interests will lead to noncompliance by company management (taxpayers) which will result in companies avoiding tax (tax avoidance). According to Xynas (Dewinta and Setiawan, 2016), tax avoidance is an effort to reduce tax debt that is legal (lawful). Tax avoidance done by companies is to reduce taxes, but still comply with applicable tax regulations. Tax avoidance actions by companies such as deferring taxes that have not been regulated in tax regulations and take advantage of exceptions and deductions allowed in tax regulations (Dewinta and Setiawan, 2016). Uppal (Dewinta and Setiawan, 2016) states that cases of tax avoidance have occurred in developing countries, especially in Indonesia, this is done by not reporting taxes or reporting but reported not according to the actual circumstances of the income that can be imposed tax.

\section{LITERATURE REVIEW}

Leverage is a ratio that shows the amount of expenses incurred by a company to finance the company's operational activities. The leverage policy of the company is an indication of the practice of tax avoidance (Dharma and Ardiana, 2016). This can happen because there is an amount that must be issued, it will be issued that must be paid by the company. The tax that will be reduced becomes reduced, because there is a reduced interest before the company's tax, Adelina (in Darmawan and Sukartha 2014). In research Dewinta and Setiawan (2016) get unnecessary leverage on tax avoidance, the higher the leverage will not affect the tax avoidance activity in the company which causes the higher level of corporate income. Likewise, the results of Dharma and Ardiana's research (2016) which utilized a negative influence on tax avoidance.

Company size is considered capable of influencing companies in carrying out tax avoidance practices. Darmawan and Sukartha (2014) stated that the larger the company, the 
more the company would consider the risk in terms of managing its tax burden, large companies tend to have greater resources to carry out tax management. This statement is supported by the results of research according to Oktamawati (2017) that company size has a negative effect on tax avoidance. But the results of the study contradict the research of Dharma and Ardiana (2016) found that company size has a positive effect on tax avoidance, according to him large companies will be easier to practice tax avoidance, because large companies have superior resources compared to small companies.

Another factor that is estimated to be able to influence tax avoidance is profitability. Profitability is one measure in measuring company performance, which shows the company's ability to generate profits during a certain period (Dewinta and Setiawan, 2016). Profitability consists of several ratios, one of which is return on assets (ROA). ROA describes the ability of management to obtain profits (profits). The higher ROA, the higher the company's profit so the better the management of company assets according to Dendawijaya (2003). Research conducted by Dewinta and Setiawan (2016) found that profitability had a positive effect on tax avoidance, different results were obtained by Arianandini and Ramantha (2018) who found that profitability had a significant negative effect on tax avoidance, this was due to the more profitability of the company can position themselves in tax planning so that they are able to obtain optimal tax..

Sales growth is also considered a factor that can affect the level of tax avoidance. Sales growth can be used to predict the profits to be gained by the company. If the level of sales increases, the practice of tax avoidance will increase. This can happen because with an increase in sales, the company's profit will also increase. If profits increase, the tax costs to be paid will increase as well. Research from Hidayat (2018) found that sales growth had no effect on tax avoidance. However, different results obtained by Dewinta and Setiawan (2016) who get the results of sales growth have a positive effect on tax avoidance.

The proportion of independent directors is also considered a factor that can influence tax avoidance. The more the number of independent commissioners is expected to increase corporate governance within the company, so that it can encourage company management not to avoid tax avoidance, so that financial statements become more objective. But the results of Asri and Suardana's (2016) research concluded that the proportion of independent commissioners had no effect on tax avoidance. However, different results were obtained by Kurniasih and Sari (2013) who found that the proportion of independent commissioners had a significant simultaneous effect on tax avoidance.

\section{HYPOTHESIS DEVELOPMENT}

Leverage can affect tax avoidance, because the existence of corporate debt will result in the emergence of interest expense so that taxable income will be reduced (Oktamawati, 2017). But different research results found Hidayat (2018) which concluded that leverage does not affect tax avoidance. If the amount of company debt is large or getting higher, then the management will act conservatively (cautiously) in conducting financial reporting on the company's operations. Based on the description, the hypothesis proposed is:

$\mathrm{H} 1$ : Leverage has an significant affects tax avoidance.

The theory of political power means that companies will be more aggressive in avoiding taxes in order to achieve optimal tax burden savings (Darmawan and Sukartha, 2014). Research conducted by Dewinta and Setiawan (2016), Kurniasih and Sari (2013) found that company size had a positive effect on tax avoidance. Based on these assumptions the hypothesis in this study is as follows:

H2: Company size has an significant affects tax avoidance.

Related research has been conducted by Ariandini and Ramantha (2018) and Ayuningtyas and Sujana (2018) who stated that profitability has a negative effect on tax avoidance. The higher the value of ROA causes a better company performance. Companies with good profitability value are assumed not to do tax avoidance because high profits will be able to meet their working capital well so that they will be able to pay their taxes. Based on these assumptions the hypothesis in this study is as follows: 
H3: Profitability has an significant effect on tax avoidance.

Sales growth has an important role in working capital management, increasing sales growth can influence companies to do tax avoidance (Ayuningtyas and Sujana, 2018). If sales growth increases, companies will likely get large profits, so companies will likely do tax avoidance because large profits will also cause a large tax burden (Dewinta and Setiawan, 2016). Strengthened by the results of Oktamawati's research (2017) which states that sales growth has a positive effect on tax avoidance. Based on these assumptions the hypothesis in this study is as follows:

H4: Sales Growth has an significant affects tax avoidance.

Independent commissioners in the company can provide direction to managers to manage the company and formulate strategies that the company can do to better include in determining policies regarding tax payments (Ayuningtyas and Sujana, 2018). Research conducted by Asri and Suardana (2016) and Ayuningtyas and Sujana (2018) state that the proportion of commissioners has no effect on tax avoidance. Based on these assumptions the hypothesis in this study is as follows:

H5: The proportion of Independent Commissioners influences tax avoidance.

\section{METHODS OF RESEARCH}

The variable used in this study is Tax Avoidance, the measurement of tax avoidance in this study is calculated through the CURRENT ETR (current effective tax rate) ratio is sought by comparing the cash incurred for tax costs (current tax burden) divided by profit before tax (Hidayat, 2018). If the ETR value is getting smaller then the tax avoidance action is getting bigger. The formula is as follows:

$$
\text { CURRENT ETR }=\frac{\text { Current Tax Expense }}{\text { Pre tax Income }}
$$

Where: CETR = Tax Avoidance.

Leverage is the ratio used to find out how much the company's assets are financed by debt. According to Fahmi (2011: 62) the use of debt that is too high will make the company trapped in a high level of debt and difficult to release the debt burden. Likewise with Hanafi and Halim (2012: 75) which explains the leverage ratio is a ratio that measures the ability of a company to meet its long-term obligations. In this study leverage is measured by the total debt to equity ratio using the following formula:

$$
\text { Debt to Equity Ratio }(D E R)=\frac{\text { Total Hutang }}{\text { Total Ekuitas }}
$$

Company size according to Riyanto (2008: 313 ) is the size of the company seen from the size of the equity value, the value of sales and the value of assets. The size of the company is shown through the log of total assets, because it is considered that this measure has a more stable level than other proxies and is continuous between periods (Hartono, 2007: 282). The size of the company is formulated as follows:

Ukuran perusahaan $=\log ($ total asset $)$

Profitability is a ratio that measures a company's ability to generate profits by taking into account the capital used. In this study the formula used is Return On Assets (ROA). ROA formula as follows:

$$
\mathrm{ROA}=\frac{\text { Laba Setela } h \text { Pajak }}{\text { Total Asset }}
$$


Both the bad level of sales (sales growth) has an important role in the management of company working capital (Dewinta and Setiawan, 2016). The sales growth formula is as follows:

$$
\mathrm{G}=\frac{S 1-S 0}{S 0} X 100 \%
$$

Where: $\mathrm{G}=$ Growth Sales; $\mathrm{S} 1=$ Total Current Sales; $\mathrm{S} 0=$ Total Sales for Last Period.

The role of an effective Independent commissioner in a company will prevent the practice of tax avoidance. More and more the proportion of independent commissioners who control the company's obligations in paying taxes will be reflected from the company's high CETR, thus illustrating the company's low tax avoidance actions.

Kind $=\frac{\text { Amount Proportion of Commissioners }}{\text { Amount of All Commissioners }}$ X 100\%

Population is a generalization area consisting of objects or subjects that have certain quantities and characteristics determined by researchers to be studied and then drawn conclusions (Sugiyono, 2014: 80). The population used in this study is manufacturing companies listed on the Indonesia Stock Exchange (IDX) on Kompas100 in a row in the period $2015-2018$.

The determination of the sample in this study is based on the nonprobability sampling method with judgmental sampling technique wherein the withdrawal of nonprobability samples based on certain criteria (Sudaryono, 2018; 174), is as follows:

1. Companies registered as industrial sub consumer goods manufacturing companies on Komp100 during the study, namely 2015 - 2018;

2. Sub-consumer goods manufacturing companies in Kompas 100 which have complete annual financial report data and provide annual reports;

3. Sub consumer goods industry manufacturing companies in compass 100 whose financial statements are expressed in rupiah;

4. Sub consumer goods industry manufacturing companies in Kompas100 whose financial statements did not experience losses during the 2015-2018 research period.

This study uses quantitative data, while the source of the data used in this study is secondary data in the form of financial statements for the period of 2015 - 2018 which have been published by the Indonesia Stock Exchange and can be downloaded from the IDX (Indonesia Stock Exchange) page.

The secondary data collection method in this study uses the documentation method which is a data collection technique by collecting and collecting data obtained from previous research and published annual company reports. The data collection in this study was carried out by tracing the 2015-2018 annual report. Data sources were obtained from the Indonesia Stock Exchange (IDX) website, namely www.idx.co.id and google.com

Data analysis conducted in this study included descriptive statistical tests, classic assumption tests, panel data regression analysis, $\mathrm{F}$ tests and tests.

\section{RESULTS OF STUDY}

The objects in this study are companies listed on the Indonesia Stock Exchange (IDX) in Kompas 100 for the 2015-2018 period engaged in manufacturing consumer goods industry sub-sector, which amounted to eight (8) companies.

Data analysis using panel data regression analysis techniques. This analysis was processed using Eviews 10. Test classic assumptions to ensure that the regression model used is free from problems of normality, multicollinearity, heteroscedasticity, and auto correlation. 
The $F$ test is used to find out whether the independent variables together significantly influence the dependent variable. From the results of data processing using Eviews 10, here are the results of the statistical $F$ test:

Table 1 - Result F Test

\begin{tabular}{lllll}
\hline Variable & Coefficient & Std. Error & t-Statistic & Prob. \\
\hline \hline C & 0.157488 & 0.153723 & 1.024497 & 0.3185 \\
DER & 0.013583 & 0.009600 & 1.414771 & 0.1733 \\
SIZE & 0.012183 & 0.020075 & 0.606845 & 0.5511 \\
ROA & -0.003364 & 0.022184 & -0.151660 & 0.8811 \\
GROWTH & 0.064189 & 0.029547 & 2.172422 & 0.0427 \\
PK & 0.009494 & 0.010679 & 0.889078 & 0.3851 \\
\hline \hline
\end{tabular}

Effects Specification

Cross-section fixed (dummy variables)

\begin{tabular}{|c|c|c|c|}
\hline \multirow{6}{*}{$\begin{array}{l}\text { R-squared } \\
\text { Adjusted R-squared } \\
\text { S.E. of regression } \\
\text { F-statistic } \\
\text { Prob(F-statistic) }\end{array}$} & \multicolumn{3}{|c|}{ Weighted Statistics } \\
\hline & 0.950258 & Mean dependent var & 0.558150 \\
\hline & 0.918843 & S.D. dependent var & 0.440862 \\
\hline & 0.012527 & Sum squared resid & 0.002982 \\
\hline & 30.24785 & Durbin-Watson stat & 2.310752 \\
\hline & 0.000000 & & \\
\hline & \multicolumn{3}{|c|}{ Unweighted Statistics } \\
\hline R-squared & 0.901280 & Mean dependent var & 0.269021 \\
\hline Sum squared resid & 0.003164 & Durbin-Watson stat & 2.707695 \\
\hline
\end{tabular}

Sources: Output Eviews 10.

The statistical $F$ test results of the statistical probability value is $0.00<0.05$, meaning Debt to Equity Ratio (DER), Company Size (SIZE), Return on Assets (ROA), Sales Growth (GROWTH), Proportion of Independent Commissioners (PK) simultaneously has a significant effect on Tax Avoidance in manufacturing companies registered in Kompas 100 for the 20152018 period.

Table 2 - Determination Test Result

\begin{tabular}{|c|c|}
\hline R-squared & 0.950258 \\
\hline Adjusted R-squared & 0.918843 \\
\hline S.E. of regression & 0.012527 \\
\hline F-statistic & 30.24785 \\
\hline Prob(F-statistic) & 0.000000 \\
\hline
\end{tabular}

Sources: Output Eviews 10.

Table 2 shows that the adjusted R-square value is 0.918843 or 91.88 percent. This shows that a set of independent variables are able to explain the dependent variable of 0.918843 or $91.88 \%$, so there is an $8.12 \%$ value of the dependent variable that is influenced by factors outside the independent variable in the study.

\section{DISCUSSION OF RESULTS}

Effect of Leverage on Tax Avoidance. The results of this study prove that Leverage has no effect on Tax Avoidance, but these results are not consistent with the results of Ayuningtyas and Sujana's research which states that Leverage has a significant effect on 
Tax Avoidance. The results of this study indicate that companies do not use debt to avoid tax. According to Sugitha and Supadhmi (2016) said that companies use debt obtained for investment purposes so as to generate income outside the company's business. This makes the profits earned by the company rise and affect the increase in tax burden borne by the company.

Effect of Company Size on Tax Avoidance. The results of this study prove that company size has no effect on tax avoidance, but these results are not consistent with Kurniasih and Sari's research which says that company size has an effect on tax avoidance. According to Oktamawati (2017) states that the greater the size of the company, then to maintain the company's image in the eyes of the public the company management will tend not to avoid tax avoidance.

Effect of Profitability on Tax Avoidance. The results of this study prove that profitability has no effect on Tax Avoidance, this result is consistent with research Sugitha and Supadhmi (2016) which says that profitability has no effect on Tax Avoidance. Companies that have high profits will be able to meet their working capital well, so they will be able to pay high taxes (high CETR value), this shows that the practice of tax avoidance in the company is low (Ayuningtyas and Sujana, 2018).

Effect of Sales Growth on Tax Avoidance. The results of this study prove that Sales Growth affects Tax Avoidance, this result is consistent with Dewinta and Setiawan's research which says that Sales Growth affects Tax Avoidance. According to Oktamawati (2017) said that companies with high sales growth rate means that they have good performance and company profits tend to increase, so that tax payments will also be high, the management will make tax savings.

Effect of Proportion of Independent Commissioners on Tax Avoidance. The results of this study prove that the Proportion of Independent Commissioners has no effect on Tax Avoidance, thus H5 states that the Proportion of Independent Commissioners has a negative effect on Tax Avoidance received. This result is consistent with Ayuningtyas and Sujana's research which states that the Proportion of Independent Commissioners has no effect on Tax Avoidance. According to Annisa (2012) in Winata (2014) said that the greater the percentage of variables the proportion of Independent Commissioners can be used to supervise and control a company by directors and management so that their existence is not just mere formality.

\section{CONCLUSION AND RECOMMENDATIONS}

Based on research conducted to determine the effect of Leverage, Company Size, Profitability, Sales Growth, and the Proportion of Independent Commissioners on Tax Avoidance in 2015 - 2018, it can be concluded that Leverage proxied by DER has no effect on tax avoidance, this can be seen from the probability value is 0.1733 where the value is greater than 0.05. Because the higher the value of leverage the higher the cost of interest from third party debt and will affect the reduced profit before corporate tax. This result is consistent with the results of Sugitha and Supadhmi's research which states that leverage has no effect on tax avoidance.

Company size has no effect on tax avoidance, this can be seen from the probability value of 0.5511 where the value is greater than 0.05 . Because the larger the size of the company, the lower the company will do tax avoidance. These results are consistent with Oktamawati's study which states that company size has no effect on tax avoidance. Profitability which is proxied by ROA has no effect on tax avoidance, this can be seen from the probability value of 0.8811 where the value is greater than 0.05 . Because the lower the profitability, the higher the tax avoidance means that the higher the value of ROA causes good company performance so that the profit will also be high so that it will be able to meet its working capital and be able to pay taxes. These results are in accordance with Ayuningtyas and Sujana's research which states profitability has no effect on tax avoidance.

Sales growth affects tax avoidance, this can be seen from the probability value of 0.0427 where the value is smaller than 0.05 , meaning that large sales growth companies will 
do tax avoidance, this is because the profits generated will be large. This result is consistent with Dewinta and Setiawan's research which says that sales growth affects tax avoidance.

The proportion of independent directors has no effect on tax avoidance, this can be seen from the probability value of 0.3851 where the value is greater than 0.05 . this means that the more independent commissioners in a company, the more effective management supervision will be. This result is consistent with Ayuningtyas and Sujana's research which says that the proportion of independent directors has no effect on tax avoidance.

In conducting this research, there are several limitations faced as follows:

- Variables used in this study only use leverage proxied by Debt to Equity Ratio, Company Size, Profitability, Sales Growth, and Proportion of Independent Commissioners;

- In this study only focuses on companies registered in Kompas100 in the manufacturing sector in the $2015-2018$ period;

- The time in this study is relatively short, namely only 4 periods from 2015-2018.

Based on the conclusions of the research discussed earlier, the recommendations that can be taken into consideration for further research include:

- For further researchers, it is expected to be able to add or use other independent variables that are different from this research variable, which can affect tax avoidance;

- For further researchers, it is expected to conduct research on all companies listed on the Indonesia Stock Exchange, not only on companies listed on Kompas100;

- For further researchers, it is expected to extend the observation period to get an idea whether the research results obtained are consistent with previous studies.

\section{REFERENCES}

1. Arianandini, P., \& Ramantha, I. (2018). Pengaruh Profitabilitas, Leverage, dan Kepemilikan Institusional Pada Tax Avoidance. Pengaruh Profitabilitas, Leverage, Dan Kepemilikan Institusional Pada Tax Avoidance, 53(9), 1689-1699. https://doi.org/10.1017/CBO9781107415324.004 ISSN: 2302-8556.

2. Asri, I. A. T. Y., \& Suardana, K. A. (2016). Pengaruh Proporsi Komisaris Independen, Komite Audit, Preferensi Risiko Eksekutif Dan Ukuran Perusahaan Pada Penghindaran Pajak. E-Jurnal Akuntansi, 16(1), 72-100. ISSN: 2302-8556.

3. Ayuningtyas. N., \& Sujana, I. (2018). Pengaruh Proporsi Komisaris Independen, Leverage, Sales Growth, Dan Profitabilitas Pada Tax Avoidance. Pengaruh Proporsi Komisaris Independen, Leverage, Sales Growth, Dan Profitabilitas Pada Tax Avoidance, 53(9), 1689-1699. https://doi.org/10.1017/CBO9781107415324.004 ISSN: 2302-8556.

4. Basuki, A. T. dan Prawoto, N. (2017). Analisis Regresi Dalam Penelitian Ekonomi \& Bisnis: Dilengkapi Aplikasi SPSS \& EVIEWS. Depok: PT Rajagrafindo Persada.

5. Darmawan, I., \& Sukartha, I. (2014). Pengaruh Penerapan Corporate Governance, Leverage, Roa, Dan Ukuran Perusahaan Pada Penghindaran Pajak. E-Jurnal Akuntansi, 9(1), 143-161. ISSN: 2302-8556.

6. Dendawijaya, L. (2003). Manajemen Perbankan. Jakarta: Ghalia Indonesia.

7. Dewinta, I. A. R., \& Setiawan, P. E. (2016). Pengaruh ukuran perusahaan, umur perusahaan, profitabilitas, leverage, dan pertumbuhan penjualan terhadap tax avoidance. E-Jurnal Akuntansi, 14, 1584-1615. Retrieved from https://ojs.unud.ac.id/index.php/Akuntansi/article/view/16009 ISSN:2302-8556.

8. Dharma, I., \& Ardiana, P. (2016). Pengaruh Leverage, Intensitas Aset Tetap, Ukuran Perusahaan, Dan Koneksi Politik Terhadap Tax Avoidance. E-Jurnal Akuntansi, 15(1), 584-613. ISSN: 2302-8556.

9. Fahmi, I. (2011). Analisis Kinerja Keuangan Panduan bagi Akademisi, Manajer, dan Investor untuk menilai dan menganalisis Bisnis dari Aspek Keuangan. Bandung: Alfabeta.

10. Ghazali, I. dan Ratmono, D. (2013). Analisi Multivariat dan Ekonometrika: Teori,Konsep dan Aplikasi dengan Eviews 8. Semarang: Universitas Diponegoro. 
11. Gujarati, D. N. dan Dwan, C. P. (2012). Dasar-dasar Ekonometrika. Edisi 5. Terjemahan Raden Carlos Mangunsong. Jakarta: Salemba Empat.

12. Hanafi, M. dan Halim, A. (2012). Analisis Laporan Keuangan. Edisi Ketiga. Yogyakarta: UPP STIM YKPN.

13. Hartono, J. (2007). Teori Portofolio dan Analisis Investasi, Edisi ketiga. Yogyakarta: BPFE.

14. Hidayat, W. W. (2018). Pengaruh Profitabilitas, Leverage Dan Pertumbuhan Penjualan Terhadap Penghindaran Pajak. Jurnal Riset Manajemen Dan Bisnis (JRMB) Fakultas Ekonomi UNIAT, 3(1), 19-26. https://doi.org/10.36226/jrmb.v3i1.82 ISSN: 2581-2165.

15. Kurniasih, T., \& Ratna Sari, M. (2013). Pengaruh Return on Assets, Leverage, Corporate Governance, Ukuran Perusahaan Dan Kompensasi Rugi Fiskal Pada Tax Avoidance. Buletin Studi Ekonomi, 18(1), 58-66. ISSN: 1410-4628.

16. Lestari, G. A. W., dan Putri, I. G. A. M. A. D. (2017). Pengaruh Corporate Governance, Koneksi Politik, Dan Leverage Terhadap Penghindaran Pajak. E-Jurnal Akuntansi Universitas Udayana Vol.18.3., 18(3), 2028-2054. ISSN: 2302-8556.

17. Mardiasmo. (2018). Perpajakan - Edisi Terbaru 2018. Yogyakarta: ANDI.

18. Maharani, I., dan Suardana, K. (2014). Pengaruh Corporate Governance, Profitabilitas, Dan Karakteristik Eksekutif Pada Tax Avoidance Perusahaan Manufaktur. E-Jurnal Akuntansi, 9(2), 525-539. ISSN: 2302-8556

19. Oktamawati, M. (2017). Pengaruh Karakter Eksekutif, Komite Audit, Ukuran Perusahaan, Leverage, Pertumbuhan Penjualan, Dan Profitabilitas Terhadap Tax Avoidance. Pengaruh Karakter Eksekutif, Komite Audit, Ukuran Perusahaan, Leverage, Pertumbuhan Penjualan, Dan Profitabilitas Terhadap Tax Avoidance, 4(30), 9-15. ISSN: 2541-5204.

20. Riyanto, B. (2008). Dasar-dasar Pembelanjaan Negara. Yogyakarta: BPFE.

21. Santi, F. Model Regresi Panel Data dan Aplikasi Eviews. (2019). Tersedia di https://osf.io > preprints > inarxiv > download.

22. Santoso, S. (2012). Statistik Parametik. Jakarta: PT Gramedia Pustaka Umum.

23. Sudaryono. (2018). Metodelogi Penelitian. Cetakan kedua. Depok: Raja Grafindo Persada.

24. Sugitha, I. M. Y. P., \& Supadmi, N. L. (2013). Pengaruh Karakteristik Perusahaan dan Beban Iklan pada Tindakan Penghindaran Pajak. Journal of Chemical Information and Modeling, 53(9), 1689-1699. https://doi.org/10.1017/CBO9781107415324.004 ISSN: 2302-8556.

25. Sugiyono. (2014). Metode Penelitian Pendidikan Pendekatan Kuantitatif, Kualitatif, dan R\&D. Bandung: Alfabeta.

26. Suwito, E., \& Herawaty, A. (2005). Industrial type, size of the company, company's profitability ratios, company's operating leverage ratios, company's net profit margin, income smoothing. SNA VII Solo, (September), 136-146.

27. Winata, F. (2014). Pengaruh Corporate Governance Terhadap Tax Avoidance Pada Perusahaan Yang Terdaftar Di Bursa Efek Indonesia Tahun 2013. Tax \& Accounting Review, 4 (1)(1), 1-11. 